\title{
Drugs modulating apoptosis: current status
}

\author{
Vimala Ananthy ${ }^{1 *}$, Raman P. Priyadharsini ${ }^{2}$, Umamaheswari Subramanian ${ }^{3}$
}

\author{
${ }^{1}$ Department of Pharmacology, Mahatma Gandhi Medical College and Research Institute, Puducherry, India \\ ${ }^{2}$ Department of Pharmacology, JIPMER, Karaikal, Puducherry, India \\ ${ }^{3}$ Department of Pharmacology, Sri Venketeshwara Medical College and Research Institute, Puducherry, India
}

Received: 03 May 2021

Accepted: 28 May 2021

\section{*Correspondence:}

Dr. Vimala Ananthy,

Email: drvimala90@gmail.com

Copyright: (C) the author(s), publisher and licensee Medip Academy. This is an open-access article distributed under the terms of the Creative Commons Attribution Non-Commercial License, which permits unrestricted non-commercial use, distribution, and reproduction in any medium, provided the original work is properly cited.

\begin{abstract}
Apoptosis (programmed cell death) is a natural process that helps in removing potentially harmful cells from the body and replacing it with normal ones. Like any other process, it is also subjected to lots of deregulations and can lead to diseases like cancer, neurodegenerative conditions, multiple sclerosis, Parkinson's disease, autoimmune disorders and inappropriate death of cells after liver failure, stroke and myocardial infarction. The knowledge of the molecular mechanisms involved in apoptosis has been progressed tremendously. Thus, therapeutics targeting apoptosis have been emerged as a novel approach for treating various disease conditions. Current approaches induce or inhibit apoptosis by targeting the key regulators of apoptosis such as Bcl2 family of proteins, TRAIL, caspases, MDM2, IAPs and p53. While many apoptotic drugs proved its efficacy in preclinical studies, some are already approved and entered the clinical setting. Numerous novel approaches such as antisense therapy, gene therapy, recombinant biologics and combinatorial chemistry are being employed to target these regulators. This review focused on the pathways of apoptosis, various therapeutic targets in apoptosis and the drugs modulating these targets.
\end{abstract}

Keywords: Apoptosis, Cell death, TRAIL, Bcl2, MDM2

\section{INTRODUCTION}

The human body is made up of approximately about 1014 cells. In order to maintain the functionality of the body system, billions of cells die every day. Apoptosis is the key mechanism involved in this process of cell death. It is a highly regulated and controlled process, which on disruption can lead to an imbalance between survival and death of the cell, resulting in cancer. Researchers identified that the key regulators of apoptosis can be used as new targets for the treatment of various disease conditions either in the pro or anti-apoptotic direction. The cytotoxicity of chemotherapeutic drugs can be improved by increasing the propensity of apoptosis in the cells.

Apoptosis is characterised by cell shrinkage, chromatin condensation, intact cell membrane and lack of inflammation. ${ }^{1}$ The toxic counterpart of apoptosis is necrosis where the cell membrane is disrupted with cellular swelling and frequently associated with inflammation. There are two main pathways of apoptosis namely the intrinsic and extrinsic pathways which form the major targets for cancer chemotherapy. This review focused on deregulations of apoptosis and the drugs involved in the modulation of various steps of apoptosis.

\section{Pathways of apoptosis}

\section{Extrinsic (death receptor) pathway}

This pathway begins with the binding of the death ligands with the death receptors located on the cell membrane. There are numerous death receptors, of which the wellknown is the tumour necrosis factor 1 receptor (TNFR1) and a related protein called FAS (first apoptic signal). The 
ligands associated with these receptors are TNF and FAS ligand, respectively. The death receptors are further associated with an intracellular death domain that gathers adapter proteins such as TNF receptor-associated death domain (TRADD), FAS-associated death domain (FADD) and cysteine proteases like caspase 8 . When the death ligand interacts with the death receptor, binding site for the adaptor protein is formed. The ligand-receptor-adaptor protein complex is known as the death inducing signalling complex (DISC). DISC activates a group of enzymes called pro-caspase 8 , the activated caspase 8 is the initiation caspase which will further activate downstream caspases called as execution caspases. The extrinsic pathway can be blocked by a protein called FLIP which binds to procaspase 8 but does not activate it due to the lack of enzymatic activity. ${ }^{2,3}$

\section{Intrinsic (mitochondrial) pathway}

As the name implies this pathway begins within the cell. This pathway gets activated as a result of increased permeability of mitochondria. The permeability of mitochondria is regulated by a group of pro and antiapoptotic proteins. The anti-apoptotic proteins are from $\mathrm{Bcl} 2$ family such as $\mathrm{Bcl} 2$ and $\mathrm{Bclx}$ which are normally located in the mitochondrial membrane and cytoplasm. When the pro-apoptotic proteins such as bak, bax and bim replace the anti-apoptotic proteins, the mitochondrial permeability is increased. Pro-apoptotic molecules are released into the cytoplasm from mitochondria without the involvement of death receptors. The proteins released from the mitochondria binds and neutralise other proteins in cytoplasm whose normal function is to block caspases and inhibit apoptosis. Cytochrome $\mathrm{c}$ is one of these proteins which binds to another protein in the cytoplasm namely apoptosis activating factor 1 (Apaf-1) and this complex activates caspase 9 . As a net result, caspase 9 which is the initiation caspase of intrinsic pathway will activate the downstream execution caspases. Another group of proteins released from mitochondria are the SMAC and HtrA2/Omi. These proteins promotes apoptosis by inhibiting IAPs (inhibitor of apoptosis proteins), which blocks the activity of caspases. ${ }^{4}$

\section{Common pathway}

This is the execution phase of apoptosis. The initiation caspase of intrinsic and extrinsic pathways namely caspase 8 and 9 respectively converge by activating the pro-caspase 3 . The executioner caspases will act on the cytoskeleton and nucleus and disrupts proteins involved in transcription, DNA replication and DNA repair. This ultimately leads to the cell death. The dying cells recruit phagocytes by secreting soluble factors into the surrounding environment and with the appearance of phosphatidylserine on the apoptotic cell membrane. This will help cells to get cleared even before the disruption of the cell membrane which is the reason for the lack of inflammation in apoptosis, unlike necrosis. ${ }^{5}$

\section{Perforin/granzyme pathway}

This pathway is used by cytotoxic T cell to kill tumor cells and virus-infected cells. It starts with the secretion of a transmembrane pore-forming molecule called perforin. This molecule helps in pore formation in the cytotoxic $\mathrm{T}$ cell followed by the release of cytoplasmic granules. The granules contain two enzymes namely granzyme A and granzyme B. Granzyme B can activate the pro-caspase 10 and cleave factors like ICAD (inhibitor of caspase activated DNAase). It is independent of the extrinsic and intrinsic pathway and directly enters the execution phase bypassing initiation phase. Granzyme B can also release cytochrome $\mathrm{C}$ thereby amplifying the death signal. ${ }^{3}$

\section{Deregulation of apoptosis}

Apoptosis is subjected to various deregulations, thus forming the pathogenesis for many disease conditions. It is usually due to an imbalance between the pro and antiapoptotic factors, reduced activity of caspases and altered signalling of death receptors. Majority of the cancer genesis is due to increased expression of the coding for antiapoptotic proteins like $\mathrm{Bcl} 2$. It has been noted that there is downregulation of FAS receptor in many cancers like melanoma, oesophageal cancers and pulmonary adenocarcinoma.

\section{Therapeutic targets in apoptosis}

The advantage of apoptosis as a therapeutic target when compared to non-apoptotic mechanisms can be appreciated only when the therapeutic index and the availability of the compounds inducing it is greater. In certain solid tumors and paediatric leukaemia, apoptosis forms a prominent mechanism for tumor remission. To achieve a suitable therapeutic index the drug should follow two strategies. They are: the drug target must be uniquely expressed in the cancer cell and it should be selectively delivered to the cancer cell. The various targets in apoptotic pathways are discussed further.

\section{Targets in extrinsic pathway}

\section{TRAIL (TNF- related apoptosis inducing ligand)}

TRAIL is a homologue of TNF and FASL which binds to the death receptor associated with death domain. It is a transmembrane protein that on binding to the death receptor recruits FADD and activates caspase 8. It was discovered that TRAIL had specificity towards the cancer cells and left the normal cells unharmed. This advantage contributed to the further development of proteins targeting TRAIL receptors. TRAIL receptors are homologous to TNFR1 and TNFR2 named as DR4 and DR5. In spite of its specificity, it showed human and animal studies which was its limitation. Unlike the other targets in apoptosis, TRAIL is not affected by the $\mathrm{p} 53$ and $\mathrm{Bcl} 2$ function. ${ }^{6,7}$ 
CD95 (FAS)

FAS receptor has been demonstrated to trigger apoptosis similar to the TNF receptors. FAS receptor mutations have been demonstrated in testicular germ cell tumors, nonsmall cell carcinoma of lung and melanoma. Thus, drugs modulating this receptor may alter cancer cell growth. FAS ligands are designed and studied for its action on tumour cell death through FAS receptor. The soluble form of the ligand produced hepatotoxicity in human studies. Thus, it was conjugated with recombinant adenovirus to enhance the cell death/killing. ${ }^{8}$

CD95 death receptor system is involved in other conditions like graft-versus-host disease (GVHD), multiple sclerosis, stroke, toxic epidermal necrolysis and liver failure. It was found that CD95 administration in mice after an ischemic injury caused a marked decrease in infarct volume and mortality. In toxic epidermal necrolysis (TEN), there is massive apoptosis with causing detachment of large area of skin. Anti CD95 antibodies were found to block the progression of TEN by inhibiting apoptosis. ${ }^{9}$

Table 1: Role of apoptosis in both physiological and pathological conditions. ${ }^{1}$

\begin{tabular}{|ll|}
\hline Physiological conditions & Pathological conditions \\
\hline During embryogenesis & $\begin{array}{l}\text { Cell death in degenerative disorders like Alzheimer's and } \\
\text { Parkinson's disease. }\end{array}$ \\
\hline Endometrial shedding & Cell death after myocardial infarction \\
\hline Regression of the lactating breast & Prostatic atrophy after orchidectomy \\
\hline Replacement of the gut epithelium & Virus induced cell death such as hepatitis B or C \\
\hline Involution of thymus gland & Depletion of CD4 cells in AIDS \\
\hline Ovarian follicular atresia in the menopause & Cell death that occurs in radiotherapy and chemotherapy \\
\hline
\end{tabular}

Table 2: Status of agents targeting death receptors. ${ }^{8,9}$

\begin{tabular}{|c|c|c|c|c|}
\hline $\begin{array}{l}\text { Molecular } \\
\text { targets }\end{array}$ & Drugs & Principles & Experimental effects & Clinical status \\
\hline \multirow{4}{*}{$\begin{array}{l}\text { TRAIL } \\
\text { receptors }\end{array}$} & Lexatumumab & $\begin{array}{l}\text { Agonistic TRAIL-R1 } \\
\text { mAb acts on DR5 }\end{array}$ & $\begin{array}{l}\text { Apoptosis in various tumor cell lines } \\
\text { and xenografts }\end{array}$ & $\begin{array}{l}\text { Phase } 2 \text { for advanced } \\
\text { solid malignancy }\end{array}$ \\
\hline & Apomab & $\begin{array}{l}\text { Agonistic TRAIL Ab } \\
\text { acts on DR5 }\end{array}$ & Apoptosis in tumor cell lines & $\begin{array}{l}\text { Phase } 1 \text { for } \\
\text { haematological } \\
\text { cancers }\end{array}$ \\
\hline & Mapatumumab & $\begin{array}{l}\text { Agonistic TRAIL Ab } \\
\text { acts on DR4 }\end{array}$ & Apoptosis in tumor cell lines & $\begin{array}{l}\text { Phase } 1 \text { for solid } \\
\text { malignancy }\end{array}$ \\
\hline & Tigatuzumab & $\begin{array}{l}\text { Agonistic TRAIL Ab } \\
\text { acts on DR5 }\end{array}$ & & $\begin{array}{l}\text { Phase } 1 \text { for colorectal } \\
\text { cancer }\end{array}$ \\
\hline CD95/FAS & CD95-Fc & Anti CD95 antibody & Inhibition of CD95 signalling & Preclinical \\
\hline
\end{tabular}

Table 3: Status of therapeutics targeting caspases. ${ }^{9-11}$

\begin{tabular}{|lllll|}
\hline $\begin{array}{l}\text { Molecular } \\
\text { targets }\end{array}$ & Drugs & Principles & Experimental effects & Clinical status \\
\hline & Emricasan & $\begin{array}{l}\text { Irreversible caspase } \\
\text { inhibitor }\end{array}$ & $\begin{array}{l}\text { Antiapoptotic, anti-inflammatory and } \\
\text { anti-fibrotic in models of liver damage }\end{array}$ & $\begin{array}{l}\text { Phase 2 for HCV } \\
\text { infection }\end{array}$ \\
\cline { 2 - 5 } IDN-6734 & Caspase inhibitor & $\begin{array}{l}\text { Reduced heart muscle damage in } \\
\text { models of heart attack }\end{array}$ & $\begin{array}{l}\text { Phase 1 for acute } \\
\text { myocardial infarction }\end{array}$ \\
\cline { 2 - 5 } Caspase & VX-799 & $\begin{array}{l}\text { Small molecule } \\
\text { caspase inhibitor }\end{array}$ & $\begin{array}{l}\text { Effective in sepsis and neuronal death } \\
\text { model }\end{array}$ & $\begin{array}{l}\text { Phase 1 in septic } \\
\text { organ failure }\end{array}$ \\
\cline { 2 - 6 } & MX-1013 & $\begin{array}{l}\text { Dipeptide pan- } \\
\text { caspase inhibitor }\end{array}$ & $\begin{array}{l}\text { Prevents apoptosis in animal models of } \\
\text { MI, stroke and acute liver failure }\end{array}$ & $\begin{array}{l}\text { Preclinical phase for } \\
\text { stroke and liver } \\
\text { failure }\end{array}$ \\
\cline { 2 - 6 } & M-920 & $\begin{array}{l}\text { Broad spectrum } \\
\text { caspase inhibitor }\end{array}$ & $\begin{array}{l}\text { Effective against septic shock in } \\
\text { mouse models }\end{array}$ & Preclinical \\
\cline { 2 - 5 } & RGD peptides & Caspase activators & $\begin{array}{l}\text { Caspase activator in cancer but not } \\
\text { normal cells }\end{array}$ & Preclinical \\
\cline { 2 - 5 } & M-826 & $\begin{array}{l}\text { Caspase-3 specific } \\
\text { inhibitor }\end{array}$ & $\begin{array}{l}\text { Rescues neurons in Huntington's } \\
\text { disease models }\end{array}$ & Preclinical \\
\hline
\end{tabular}




\begin{tabular}{|c|c|c|c|c|}
\hline $\begin{array}{l}\text { Molecular } \\
\text { targets }\end{array}$ & Drugs & Principles & Experimental effects & Clinical status \\
\hline & M-791 & $\begin{array}{l}\text { Caspase-3 specific } \\
\text { inhibitor }\end{array}$ & $\begin{array}{l}\text { Effective against septic shock in } \\
\text { mouse models }\end{array}$ & Preclinical in sepsis \\
\hline & $\begin{array}{l}\text { Immunocasp- } \\
3 \text {, } \\
\text { immunocasp-6 }\end{array}$ & $\begin{array}{l}\text { HER } 2 \text { mAb fused to } \\
\text { caspase- } 3 \text { and } 6\end{array}$ & Growth inhibition in mouse xenograft & Preclinical \\
\hline & Ad-G/iCasp3 & $\begin{array}{l}\text { Adenoviral } \\
\text { chemically inducible } \\
\text { caspase-3 }\end{array}$ & $\begin{array}{l}\text { Reduction in tumor growth in a } \\
\text { prostate cancer mouse model }\end{array}$ & preclinical \\
\hline & PEF-F8-CP3 & $\begin{array}{l}\text { Caspase- } 3 \text { fusion } \\
\text { construct with sc- } \\
\text { antibody }\end{array}$ & $\begin{array}{l}\text { Antigen dependent induction of } \\
\text { apoptosis }\end{array}$ & Preclinical \\
\hline & $\begin{array}{l}\text { FKBP12/casp- } \\
9\end{array}$ & $\begin{array}{l}\text { Chemically inducible } \\
\text { caspase-9 }\end{array}$ & Anti-angiogenic in mouse models & Preclinical \\
\hline
\end{tabular}

\section{Caspase inhibitor/activator}

Caspases form the core component of apoptotic pathways. It is a cysteinyl aspartate specific protease which require aspartic acid residue for its action. Experiments using caspase knockout and transgenic mice have shown that inhibition of caspases has therapeutic potential in degenerative and inflammatory diseases like rheumatoid arthritis, liver injury and myocardial infarction. Currently, the caspase inhibitor forms an important role in apoptosis based drug development. Liver disease such as hepatitis B, hepatitis $\mathrm{C}$ and alcoholic liver disease shows accelerated apoptosis. In animal models, it has been shown that caspase inhibitor benzyloxycarbonyl-val-ala-aspfluoromethylketone (z-VAD-fmk) have considerable reduction in apoptosis mediated liver injury. It reduced sepsis associated apoptosis of lymphocytes to a great extent and improved survival rates in mouse models. Moreover, there was reduced infarct size and neuronal damage after stroke in similar models. Not only the cells survived but there was a sustained functionality of the cells. ${ }^{10}$

The limitation with caspase inhibitor is poor cell permeability and lack of stability. This is due to the peptidyl structure and carboxylic acid residues. These limitations can be overcome by stepwise reduction in the peptidic nature and use of compounds mimicking peptide backbone. Similarly, caspase activators were designed to induce apoptosis in tumor cells. Several compounds are designed that could induce caspases, including direct caspase activators and inducible caspases. ${ }^{10}$

\section{Targets in intrinsic pathway}

\section{Inhibitor of apoptosis proteins (IAP)}

IAPs are a group of important proteins that regulate apoptosis with the help of one or two protein modules called baculovirus IAP repeats (BIR). They bind to caspases and inhibit apoptosis. XIAP is the most widely studied IAP, which inhibit caspase 3, caspase 7 and caspase
9. IAPs are important targets which on inhibition can be used as therapeutics in various cancers such as multiple myeloma. On the other hand, it can be used for inhibiting apoptosis and cell death in neurodegenerative disorders such as Parkinson's disease and cerebral ischemia. Survivin is another member of IAPs containing a single BIR which is expressed in high levels in cancer cells when compared to normal cells. Antisense oligonucleotides are designed against the mRNA of XIAP and survivin that act as an adjuvant to chemo and radiotherapy. It was already discussed that a mitochondrial protein namely SMAC inhibit IAP. Currently, many companies are targeting this protein and developing SMAC peptides and SMACmimetic drugs to inhibit IAPs and restore caspase activity. ${ }^{12}$

\section{Bcl2 family proteins}

Bcl2 family proteins play an important role in the intrinsic pathway of apoptosis. They contain both pro and antiapoptotic group of proteins and thus are an important target for cancer therapy. The pro-apoptotic group contains proteins such as BAX and BAK that will increase the mitochondrial permeability and release cytochrome $\mathrm{c}$ and activates caspases. Drugs mimicking these proteins are designed to induce apoptosis. The anti-apoptotic group of Bcl2 family are over-expressed in most of the cancers which correlates with increased resistance to chemotherapy and poor survival rates.

The drugs targeting Bcl2 proteins will either be those affecting the gene expression of $\mathrm{Bcl} 2$ or those directly affecting the protein itself. Oblimersen, is an antisense drug targeted against Bcl 2 mRNA. Small molecules like ABT723 is designed to act directly against $\mathrm{Bcl} 2$ and $\mathrm{Bclx}$ and shown to cause regression of tumour size in animal models. ${ }^{13}$

\section{MDM2 inhibitors}

MDM2 is a protein that binds to tumour suppressor p53 and inhibits its activity. This inhibition blocks the cell cycle 
progression into apoptosis. It was also shown that MDM2 is overexpressed in cancer cells. Thus, designing p53 mimetics can bind to MDM2 and displace p53. Nutilins are one example of MDM2 antagonist which mimics p53. It caused p53 activation and cell cycle arrest in xenograft mouse models without any significant toxicity. The action was more in cells containing wild type p53. ${ }^{14}$

\section{Other targets}

\section{Phosphatidylinositol 3-kinase (P13K)-AKT pathway}

Both extrinsic and intrinsic pathways are regulated by P13K-AKT. AKT phosphorylates and inactivates BAD (pro-apoptotic protein) and apoptosis signal regulating kinase. It also regulates FAS, IAP and nuclear factor of $\kappa B$.
Moreover, this pathway includes mechanistic target of rapamycin (mTOR), which belongs to P13k family of kinases. It is inhibited by rapamycin and its analogues and thus, slows down the cell growth. Thus, these pathways act as a potential target for modulating apoptosis. ${ }^{15}$

\section{Proteasome}

Proteasome is a multi-subunit enzyme complex involved in polyubiquitination and protein turnover. Proteasome inhibitors have pro-apoptotic action by downregulating Bcl-2, causing misbalance between pro and anti-apoptotic proteins, inducing death receptors, death ligands and caspases. Bortezomib is the first proteasome inhibitor already approved for multiple myeloma. ${ }^{16}$

Table 4: Therapeutics targeting intrinsic pathway.,12

\begin{tabular}{|c|c|c|c|c|}
\hline $\begin{array}{l}\text { Molecular } \\
\text { targets }\end{array}$ & Reagents & Principles & Experimental effects & Clinical status \\
\hline \multirow{4}{*}{ XIAP } & BIR3 antagonists & Antagonist of IAPs & Pro-apoptotic in tumor cell lines & Preclinical \\
\hline & $\begin{array}{l}\text { Polyphenylurea } \\
\text { derivatives }\end{array}$ & $\begin{array}{l}\text { BIR2-specific non- } \\
\text { peptide inhibitors }\end{array}$ & Direct stimulation of caspase activity & $\begin{array}{l}\text { Preclinical for } \\
\text { leukaemia cells }\end{array}$ \\
\hline & Embelin & $\begin{array}{l}\text { Herbal cell- } \\
\text { permeable XIAP } \\
\text { inhibitor }\end{array}$ & $\begin{array}{l}\text { Induces apoptosis in XIAP } \\
\text { overexpressing cells }\end{array}$ & $\begin{array}{l}\text { Preclinical for } \\
\text { prostate cancer }\end{array}$ \\
\hline & AEG35156 & $\begin{array}{l}\text { XIAP antisense } \\
\text { oligonucleotide }\end{array}$ & $\begin{array}{l}\text { Antitumor activity in xenograft } \\
\text { models }\end{array}$ & $\begin{array}{l}\text { Preclinical for acute } \\
\text { myeloid leukaemia }\end{array}$ \\
\hline \multirow{2}{*}{ Survivin } & LY2181308 & $\begin{array}{l}\text { Survivin antisense } \\
\text { construct }\end{array}$ & $\begin{array}{l}\text { Antitumor activity in preclinical } \\
\text { studies }\end{array}$ & $\begin{array}{l}\text { Phase } 2 \text { for prostate } \\
\text { cancer }\end{array}$ \\
\hline & $\begin{array}{l}\text { Ad-survivin } \\
\text { t34A }\end{array}$ & $\begin{array}{l}\text { Survivin mutant } \\
\text { adenovirus }\end{array}$ & Apoptosis in breast cancer xenografts & Phase 1 \\
\hline SMAC & Birinapant & Inhibits IAP & $\begin{array}{l}\text { Enhances cisplatin induced apoptosis } \\
\text { in prostatic cancer cells }\end{array}$ & $\begin{array}{l}\text { Phase } 1 \text { for } \\
\text { lymphomas }\end{array}$ \\
\hline \multirow{3}{*}{ Bcl2 } & Oblimersen & $\begin{array}{l}\text { Bcl2 antisense } \\
\text { oligonucleotide }\end{array}$ & Blocks Bcl2 mRNA & $\begin{array}{l}\text { Phase } 3 \text { for } \\
\text { haematological } \\
\text { cancer }\end{array}$ \\
\hline & $\begin{array}{l}\text { Antimycin A } \\
\text { derivatives }\end{array}$ & Inhibits Bcl2 & Induce apoptosis by blocking Bcl2 & Preclinical \\
\hline & Chelerythrine & $\begin{array}{l}\text { Plant alkaloid } \\
\text { inhibiting Bcl2 }\end{array}$ & $\begin{array}{l}\text { Induces cell death in } \mathrm{Bcl} 2 \text { and } \mathrm{Bclx} \\
\text { overexpressing cancers }\end{array}$ & Preclinical \\
\hline \multirow{6}{*}{ P53 } & $\begin{array}{l}\text { INGN2 } \\
\text { (ADVEXIN) }\end{array}$ & $\begin{array}{l}\text { P53 expressing } \\
\text { adenovirus }\end{array}$ & Induces apoptosis in xenograft models & $\begin{array}{l}\text { Phase } 3 \text { for head and } \\
\text { neck cancer }\end{array}$ \\
\hline & ONYX-015 & $\begin{array}{l}\text { P53 delivery with } \\
\text { mutant adenovirus }\end{array}$ & $\begin{array}{l}\text { Virus demonstrates significantly } \\
\text { greater antitumor activity }\end{array}$ & $\begin{array}{l}\text { Phase } 2 / 3 \text { for } \\
\text { squamous cell cancer }\end{array}$ \\
\hline & Amifostine & Restoration of p53 & $\begin{array}{l}\text { Restoration of transcriptional activity } \\
\text { of p53 }\end{array}$ & $\begin{array}{l}\text { Established as a } \\
\text { chemo- and } \\
\text { radioprotector. }\end{array}$ \\
\hline & Nutlins & $\begin{array}{l}\text { Imidazoline } \\
\text { derivatives that } \\
\text { antagonize p53 }\end{array}$ & $\begin{array}{l}\text { Drugs bind with } \mathrm{p} 53 \text { pocket of MDM } \\
2\end{array}$ & Preclinical \\
\hline & Chalcones & P53 antagonist & $\begin{array}{l}\text { Compounds with insufficient } \\
\text { specificity }\end{array}$ & Preclinical \\
\hline & Pifithrin- $\alpha$ & $\begin{array}{l}\text { Synthetic p53 } \\
\text { inhibitor }\end{array}$ & Inhibits p53 dependent transcription & Preclinical \\
\hline
\end{tabular}


Table 5: Proteasome inhibitors. ${ }^{17}$

\begin{tabular}{|lllll|}
\hline $\begin{array}{l}\text { Molecular } \\
\text { targets }\end{array}$ & Drugs & Principles & Experimental effects & Clinical status \\
\hline & Bortezomib & $\begin{array}{l}\text { Dipeptide boronic } \\
\text { acid- proteasome } \\
\text { inhibitor }\end{array}$ & $\begin{array}{l}\text { Misbalance between pro and } \\
\text { antiapoptotic proteins }\end{array}$ & $\begin{array}{l}\text { Approved for } \\
\text { multiple myeloma }\end{array}$ \\
\cline { 2 - 5 } $\begin{array}{l}\text { Proteaso } \\
\text { me }\end{array}$ & Ritonavir & Protease inhibitor & $\begin{array}{l}\text { Inhibits chymotrypsin-like activity of } \\
\text { proteasome }\end{array}$ & $\begin{array}{l}\text { Phase 2 in tumor } \\
\text { patients }\end{array}$ \\
\cline { 2 - 6 } & MLN519 & $\begin{array}{l}\text { Proteasome } \\
\text { inhibitor }\end{array}$ & $\begin{array}{l}\text { Anti-inflammatory and neuroprotective } \\
\text { effects }\end{array}$ & $\begin{array}{l}\text { Phase } 1 \text { for } \\
\text { myocardial } \\
\text { infarction }\end{array}$ \\
\cline { 2 - 6 } & Carfilzomib & $\begin{array}{l}\text { Proteasome } \\
\text { inhibitor }\end{array}$ & $\begin{array}{l}\text { Misbalance between pro and } \\
\text { antiapoptotic proteins }\end{array}$ & $\begin{array}{l}\text { Approved for } \\
\text { multiple myeloma }\end{array}$ \\
\hline
\end{tabular}

\section{CONCLUSION}

As the knowledge of the intricate mechanisms of apoptosis increases, the ways in which they get deregulated and the ability to design drugs targeting such mechanisms grows. Despite many preclinical studies validate the use of these targets, only a minor percentage of such molecules enters the clinical setting. This is due to the lack of stability, impermeability and peptidic nature of these small molecules. With further effects to maximize the potency, these drugs can give promising results in the treatment of various disease conditions.

Funding: No funding sources Conflict of interest: None declared Ethical approval: Not required

\section{REFERENCES}

1. Cotran RS. Cellular pathology I: cell injury and cell death. In: Kumar V, Collins T, eds. Pathologic basis of disease. 8th ed. Philadelphia: Elsevier Saunders; 2005.

2. Gomez-Sintes R, Hernandez F, Lucas JJ, Avila J. GSK-3 mouse models to study neuronal apoptosis and neurodegeneration. Front Mol Neurosci. 2011;4:45-7.

3. Elmore S. Apoptosis: a review of programmed cell death. Toxicol Pathol. 2007;35(4):495-516.

4. Solary E, Droin N, Sordet O, Rebe C, Filomenko R, Wotawa A, et al. Cell death pathways as targets for anticancer drugs. In: Sordet O, Rebe C, Filomenko R, eds. Anticancer development. 5th ed. San Diego: Academic Press; 2002.

5. Ghobrial IM, Witzig TE, Adjei AA. Targeting apoptosis pathways in cancer therapy. CA Cancer J Clin. 2005;55(3):178-94.

6. Wong RSY. Apoptosis in cancer: from pathogenesis to treatment. J Exp Clin Cancer Rev. 2011;30:87-9.

7. Palacios C, Yerbes R, Sanchez T, Martin R, Cano A, Lopez-Rivas A. The long and winding road to cancer treatment: the TRAIL system. Curr Pharm Des. 2014;20(17):2819-33.
8. Rosa AJ, Gomez MA, Morales S, Padillo FJ, Muntane J. CD95 signaling in cancer treatment. Curr Pharm Des. 2014;20(17):2809-18.

9. Fischer U. New approaches and therapeutics targeting apoptosis in disease. Pharmacol Rev. 2005;57(2):187215.

10. Kim R, Emi M, Tanabe K. Caspase-dependent and independent cell death pathways after DNA damage. Oncol Rep. 2005;14:595-9.

11. McIlwain DR, Berger T, Mak TW. Caspase functions in cell death and disease. Cold Spring Harb Perspect Biol. 2013;5:18-20.

12. Fulda S, Vucic D. Targeting IAP proteins for therapeutic intervention in cancer. Nat Rev Drug Discov. 2012;11(2):109-24.

13. Um H. Bcl-2 family proteins as regulators of cancer cell invasion and metastasis: a review focusing on mitochondrial respiration and reactive oxygen species. Oncotarget. 2016;7(5):5193-203.

14. Zhao Y, Aguilar A, Bernard D, Wang S. Smallmolecule inhibitors of the MDM2-p53 protein-protein interaction (MDM2 inhibitors) in clinical trials for cancer treatment. J Med Chem. 2015;58(3):1038-52.

15. Kang MH, Oh SC, Lee HJ, Kang HN, Kim JL, Kim JS, et al. Metastatic function of BMP-2 in gastric cancer cells: the role of PI3K/AKT, MAPK, the NF$\kappa \mathrm{B}$ pathway, and MMP-9 expression. Exp Cell Res. 2011;317(12):1746-62.

16. Kisselev AF, Linden WAVD, Overkleeft HS. Proteasome inhibitors: an expanding army attacking a unique target. Chem Biol. 2012;19(1):99-115.

17. Accardi F, Toscani D, Bolzoni M, Palma BD, Aversa F, Giuliani N. Mechanism of action of bortezomib and the new proteasome inhibitors on myeloma cells and the bone microenvironment: impact on myelomainduced alterations of bone remodeling. Biomed Res Int. $2015 ; 15: 172-88$.

Cite this article as: Ananthy V, Priyadharsini RP, Subramanian U. Drugs modulating apoptosis: current status. Int J Basic Clin Pharmacol 2021;10:870-5. 